\title{
Comparativism and THE New Hungarian FundaMental LAW - TAKing RAZ SERIOUSLY
}

\author{
Attila Badó \& Péter Mezei ${ }^{1}$ \\ Faculty of Law, University of Szeged, Hungary \\ attila@badoat.hu; mezei@juris.u-szeged.hu
}

BADÓ, Attila; MEZEI, Péter. Comparativism and the New Hungarian Fundamental Law - Taking Raz Seriously. International and Comparative Law Review, 2017, vol. 17, no. 1, pp. 109-127. DOI 10.2478/iclr-2018-0004.

\begin{abstract}
Summary: Comparative law plays a role both at the time of the creation and interpretation of constitutions. Hungary is not an exception in this respect. The comparative analysis of Hungarian constitutional law is an ordinary one both in terms of quantity and quality. The new Fundamental Law of 2011 as well as the "two-third majority statutes", however, led to an international scandal. Several studies have suggested that the method of acceptance of the new Fundamental Law and its content are unique in several aspects. The reviews of the Fundamental Law by scholars and international organizations show, however, contradictory opinions. We argue that such opposition is mainly due to differing conceptions of the ideal democratic society. Proponents of the Fundamental Law asserting national sovereignty and the supremacy of legislation accept any constitutional regulation that is backed by the necessary amount of votes. On the other hand, opponents have disliked everything that has happened in Hungarian constitutional law since 2010 on the premises of global constitutional values, the lack of consensus, selfrestraint or elegance. The present paper aims to evaluate the Fundamental Law of Hungary through the lens of Joseph Raz's seven constitutional criteria that might serve as a structured approach to analysis that is acceptable to those who express supportive as well as critical opinions on the Fundamental Law. Indeed, based upon Raz's criteria we have come to the conclusion that the new constitutional regime does not meet one single criterion that is connected to its acceptance. As the Fundamental Law was accepted rapidly, without any endorsement by the opposing parties or any referendum, it cannot be demonstrated that it mediates general values accepted by the whole society.
\end{abstract}

Keywords: Fundamental Law, Hungary, constitutionality, Joseph Raz, comparative law

\section{Introduction}

Traditionally, codified constitutions may be divided into two major parts: provisions on fundamental rights and rules determining the functioning of state

1 Attila Badó is a Professor of Law at the University of Szeged, Faculty of Law, Institute of Comparative Law. Péter Mezei is an Associate Professor of Law at the University of Szeged, Faculty of Law, Institute of Comparative Law. The authors are grateful to Prof. Benjamin G. Davis, Prof. Evan C. Zoldan and Dr. Sándor Hettinger for their comments and contribution to the finalizing of the present paper. 
structures. In both cases, complying with international requirements is indispensable since a number of issues are prescribed by international treaties and documents for State Parties. This is particularly true as regards human rights; however, EU-level cooperation is permeated in part into the state structure framework of EU Member States such as legislation, enforcement and justice as well. Apart from this, naturally, every state has a right to codify rules embodying its own national interests into its constitution. However, these individual norms have now been built into a global "constitutional framework".

\section{Comparativism and enforcement}

The mere words of a constitution are unsuitable for reflecting a country's constitutional order and, particularly, its operation. In other words, it is not the form and content of provisions that exclusively ensure constitutionality, but the enforcement of constitutions as well. Courts play a central role in guaranteeing this regardless of being part of the ordinary judicial system or perhaps acting as constitutional courts. It is exactly due to the "global constitutional framework" that in some cases these courts do not provide narrowly tailored solutions, but they reach their admittedly correct decisions by studying positive examples of other countries in addition to international agreements. It is at this point that comparative constitutional law may be given a role during the construction of the enforcement of legal provisions and the constitution. It is true that the need for this method is not viewed as self-evident even in democracies regarded as the most developed ones.

Justice William H. Rehnquist admitted himself that the Supreme Court of the United States did not have recourse to this method while presiding as Chief Justice. ${ }^{2}$ Indeed, as Weinrib noted: the Supreme Court's inertia in this area may involve considerable risk. Weinrib took an excellent example of Justice Antonin Scalias standpoint pertaining to rulings allowing for the execution of juvenile delinquents. Scalia believes that until the view of the American nation is not unified in the topic, the solutions of foreign countries may not be imposed upon Americans. ${ }^{3}$ According to Weinrib, the problem is not solely confined to Scalia's incorrect reading of underlying statutory provisions, but also to the fact that in the case of applying the comparative method the non-existence of any democratic country permitting juvenile capital punishment might have been clarified. ${ }^{4}$

2 Rehnquist, William H. Foreword. In Jackson, Vicki C., Tushnet, Mark (ed). Defining the Field of Comparative Constitutional Law. Westport-London: Praeger, 2002, pp. viii-ix.

3 Scalia expressed concern over this issue in his dissent to the ruling. The original text reads that "where there is not first a settled consensus among our own people, the views of other nations, however enlightened the Justices of this Court may think them to be, cannot be imposed upon Americans through their Constitution." See Thompson v. Kentucky, 487 U.S. 815 (S. Ct. 1988), p. 869.

4 "A judge would be hard-pressed to find an example - domestic or foreign, past or present - of a legal regime (excluding cultures that perform child sacrifice) that imposes juvenile, 
By ignoring the application of this method, judges relinquish the most modern means of legal and social science, thus preventing the Constitution - in the case of capital punishment, the Eighth Amendment - from "moving with the times". Naturally, this view is in constant evolution. In his dissent to the Supreme Court's new ruling permitting same-sex marriage, Chief Justice John G. Roberts, with no legal ramifications, took a "fleeting glimpse" at other countries and signalled that some "democratic countries overseas" had accepted social changes. ${ }^{6}$

In Hungary, a similar position to that of Weinrib’s was taken by János Bóka noting that although, traditionally, an overall resistance is shown against the application of foreign law, it is necessary for purposes of guidance. Indeed, as a result of the fact that the comparative method is applied during legislation and that it is clear from legal provisions and explanatory memoranda, judges would be obligated to rely upon them since "the legislator must have so provided because courts, with the aid of other public bodies or jurisprudence, where appropriate, are deemed to be suitable for getting to know the content of the foreign law and applying it."

but not adult, capital punishment". See Weinrib, Lorraine E. Constitutional Conceptions and Constitutional Comparativism. In Jackson - Tushnet, supra note 2 at p. 9.

5 "Justice Scalia denies the relevance, and even the usefulness, of the more standard elements of modern constitutional method. He thus rejects legal and social science expertise, as well as the comparative material and analysis that have become the standard judicial reference points under modern rights-protecting instruments. Consequently, the doctrinal test that recognizes an evolving standard of decency in civilized society as the Eighth Amendment's promise loses its capacity to evolve." Id. at p. 14.

6 "Here and abroad, people are in the midst of a serious and thoughtful public debate on the issue of same-sex marriage. They see voters carefully considering same-sex marriage, casting ballots in favor or opposed, and sometimes changing their minds. They see political leaders similarly reexamining their positions, and either reversing course or explaining adherence to old convictions confirmed anew. They see governments and businesses modifying policies and practices with respect to same-sex couples, and participating actively in the civic discourse. They see countries overseas democratically accepting profound social change, or declining to do so. This deliberative process is making people take seriously questions that they may not have even regarded as questions before". See James Obergefell, et al., v. Richard Hodges, et al., 135 S.Ct. 2584, 2625 (S. Ct. 2015) (Chief Justice Roberts' dissent).

7 Bóka, János. Az összehasonlító módszer alkalmazása az Alkotmánybíróság gyakorlatában. In Ambrus, István, Köblös, Adél, Strihó, Krisztina, Sulyok, Márton, Szalai, Anikó, Trócsányi, László (ed). Dikaiosz logosz - Tanulmányok Kovács István emlékére. Szeged: Pólay Elemér Alapítvány, 2012, pp. 17-18. In recent decades, a multitude of theories saw the light of day and the most renowned constitutionalists have expounded on the validity and role of (in short, the legitimacy of) the comparative reasoning in a country's legal practice. See: Tushnet, Mark. The Possibilities of Comparative Constitutional Law. The Yale Law Journal, 1999, vol. 108, pp. 1225-1309.; Choudhry, Sujit. Globalization in Search of Justification: Toward a Theory of Comparative Constitutional Interpretation. Indiana Law Journal, 1999, vol. 74, p. 819-892.; Annus, Taavi. Comparative Constitutional Reasoning: the Law and Strategy of Selecting the Right Arguments. Duke Journal of Comparative and International Law, 2004, Vol. 14, pp. 301-349.; Smits, Jan M. Comparative Law and its 
It may be reasonably understood that the attitudes of ordinary courts are varied in this respect. However, as for the Hungarian Constitutional Court, Bóka notes that it is reasonably expected that the comparative method be awarded a central role due to international uniformity of fundamental rights, national regulations with frequently identical wording, the judges' high-level qualifications or close international cooperation of constitutional courts. ${ }^{8}$ Bóka's 2012 research revealed that some $10 \%$ of the Hungarian Constitutional Court's publicly available rulings in the period between 1990 and 2010 contained comparative constitutional reasoning, which is basically identical to the ratio found in the case of the German Federal Constitutional Court. ${ }^{9}$ (Since in a number of legal systems university lecturers serve as a basis for recruitment in constitutional courts, it is presumed that the method is less preferred with ordinary courts.) The Hungarian practice seems to be weighed toward the comparative test. With some cases, the depth of applying the comparative constitutional method, which plays a role in the construction of the constitution, may procure the acknowledgement of comparative lawyers.

\section{The Fundamental Law and global constitutional values}

The extent to which courts vested with the construction of the constitution will take other countries' legal practice into consideration has not resulted in any worldwide scandal in the case of Hungary since the regime change. The 2011 constitutional process and its result, the Hungarian Fundamental Law, did not fail to make a far greater sensation which left a group of Hungarian and foreign constitutional lawyers astonished, who, committed to comparative constitutional law, viewed a number of solutions in the Fundamental law as a flagrant breach of global constitutional values. Articles on the evolution and effect of global constitutional values ${ }^{10}$ often reveal the process of convergence that may be perceivable during the birth or rebirth of national constitutions. Analyses presenting this tendency with different methods first shed light on how hastily the fundamental rights catalogue, found only in a fragmented form in the state constitutions 70 years earlier, expanded in response to a global impact. Law and Versteeg depict in spectacular charts how the number of explicitly fundamental rights provisions has grown in constitutions since the 1950s, due to, among others, the appreciation of comparative constitutional law, and how a universal catalogue on consti-

Influence on National Legal Systems. In Reimann, Mathias - Zimmermann, Reinhard (ed). The Oxford Handbook of Comparative Law. Oxford: Oxford University Press, 2006, pp. 477-512.

8 Bóka, supra note 7 at pp. $18-19$.

9 Id. at p. 21

10 Tushnet, Mark. The Inevitable Globalization of Constitutional Law. Virginia Journal of International Law, 2009, Vol. 56, pp. 985-1006.; Law, David S., Versteeg, Mila. The Evolution and Ideology of Global Constitutionalism. California Law Review, 2011, Vol. 99. pp. 1163-1257.; Chronowsky, Nóra. Az alkotmányozás a globális alkotmányozás kontextusában. Jura, 2012, Vol. 18, pp. 251-259. 
tutional principles developed, the elements of which are automatically integrated into constitutions. ${ }^{11}$

The Hungarian basic law adopted in 2011 may not be accused of having a poorly devised fundamental rights catalogue or being out of tune with the above-mentioned process. What caused the problem was that, in some cases, fundamental rights of universal scope were included in the Fundamental Law and the subsequently adopted so-called Cardinal Acts in a unique way. Thus, for example, it was highlighted that, despite its inclusion, the essence of the classical fundamental right of the freedom of religious beliefs might easily be cast away as an empty shell by its regulation, which may lead to discriminatory treatment of minority religious communities.

It is not that the Hungarian basic law would have filled the role of the "punching bag" in the international constitutional law discourse due to the lack of universal constitutional rights. If one wishes to provide explanation for the phenomenon (separated from the realms of conspiracy theories and political propaganda), it is suspected that the main problem was caused by the impression of the constitutional process that the regulation relating to state structures and fundamental rights was primarily put in place to enhance and stabilize a given political power. In spite of the pathetic wording ${ }^{12}$ and the general tone, the view was that the legislator was driven by an ambition over any other reason to hold power. The basis for this reading resulted from language with respect to the mode of adoption of the Fundamental Law to the regulation of the Chief Prosecutor's position differing from the conceptual framework of universal constitutionality and the conventional methods of the adoption of constitutions. One might also add that according to this reading, certain interests had overridden conventional global constitutional solutions in a specific political space. However, those in favour of this view do not claim either that Hungary would be considered a pioneer in this respect, since there have also been examples elsewhere that a power would create a highly advantageous situation for itself through the constitutional process authorised by it. Landau mentions the Fundamental Law of Hungary as an example of an abusive constitutional process similar to that in other states where drawing up the constitution in favour of the political power entitled to so doi was followed by the weakening of democratic rights. ${ }^{13}$ What really came as a surprise was that the above-mentioned "specific" approachese were raised to a constitutional level in an EU Member State to which even the practice of the ECHR could have posed limitations. At the same time, other views tend to take

11 See Law, Versteeg supra note 10 at pp. 1194-1257.

12 According to the wording of the Fundamental Law of Hungary as placed within the National Avowal "Our Fundamental Law shall be the basis of our legal order, it shall be an alliance among Hungarians of the past, present and future. It is a living framework which expresses the nation's will and the form in which we want to live."

13 Landau, David. Abusive Constitutionalism. UC Davis Law Review, 2013, Vol. 47, pp. 189260. 
the edge off the criticism by emphasizing that EU Member States have their own "constitutional identities" which ensures enough room for manoeuvre in determining the accurate content of the Fundamental Law. ${ }^{14}$

In comparative constitutional law the debate over the essence and the notion of the constitution is necessarily contrasted with the appearance of the particular-global conflict, which refers to a basic academic field-related problem. In the course of teaching comparative law, the lecturer warns the audience of the fact that one's understanding of certain legal systems and legal cultures is mostly burdened with the researchers' own bias and the excessive knowledge about their own legal system. Definitions in literature relating to the essence and the construction of the constitution might be traced back to this fact to which Raz draws attention in his study on the authority and construction of constitutions. He claims rather pessimistically that, unfortunately, very few useful general theories aimed at construing constitutions have been elaborated. The underlying reason for this is that the elaborated theories were drawn up based on a constitution relating to a specific legal system the general application of which defies possibility. The same goes for the notional definition of the constitution which is made rather difficult by the fact that the constitution might be perceived in a broader or a stricter sense as well. While in the first case no difficulty arises from the definition of the constitution since every legal system disposes of some legislative provisions of its own state structures, the general definition of a (codified) constitution in a stricter sense remains more problematic. In spite of this difficulty, Raz provides in his study a set of criteria consisting of seven points which we utilise in this presentation to be able to better analyse the Hungarian basic law. ${ }^{15}$

László Trócsányi, in his work on the Hungarian Fundamental Law, conducts a discourse on the fact that truths are running parallel to each other with regard to the evaluation of the Fundamental Law. ${ }^{16}$ In the authors' view, when it comes to assessing constitutions, the question of truth or "truths" may only be brought up in order to conceal or appease a conflict due to, among others, taking what has been written down by Raz into consideration. After reading critical and supportive writings, the conviction is all the more transparent that, apart from a few exceptions, the conceptions of democracy and value systems of those judging the Hungarian Fundamental Law are spectacularly and irreconcilably different from each other. This difference is further strengthened by the hysterical Hungarian political environment which immediately assumes ideological, or worse,

14 Sulyok, Márton. Értelem és érzelem vagy büszkeség és balítélet? Alkotmánybíráskodás és alkotmányos identitás. Fontes Iuris, 2015, Vol. 1., pp. 27-39.

15 Raz, Joseph. Between Authority and Interpretation: On the Theory of Law and Practical Reason. Oxford: Oxford University Press, 2009. Raz's constitutional criteria have been used by others to discuss, whether there is any "European Constitution" or not. See: Christiansen, Thomas, Reh, Christine. Constitutionalizing the European Union. China: Palgrave Macmillan, 2009, p. 42.

16 Trócsányi, László. Az alkotmányozás dilemmái. Budapest: HVG-Orac, 2014, p. 277. 
party political commitments behind the arguments and remarks seen as "professional" ones. (It might be added that, unfortunately, this assumption sometimes coincides with reality.) If the aspects of this conception about democracy essentially relating to the Hungarian Fundamental Law is intended to be depicted here without subjecting them to any profound analysis under political science, the Hungarian and international political or professional debate or party political debate disguised as a professional one might be rendered more plastic with an opposing pair of concepts revealing the essence of discourse: a representative-deliberative, a legitimate-consensual, an efficient-compromising, an interestasserting-self-restraining one, etc.

Whereas the supportive approach, based on the supremacy of legislature and the principle of popular sovereignty in an extreme case, regards as justified every regulation of the fundamental law adopted with sufficient constituent votes, massive criticism considers what has been happening in constitutional law since 2010 as unacceptable by consistently referring to global constitutional values and the lack of consensus, moderation, self-restraint and elegance. The version interpreted in constitutional terms of the two "camps" are found in traces in some opinions expressed in Constitutional Court Rulings No. 12/2013 (V. 24.) and earlier partly in No. 45/2012 (XII. 29) as well.

The basic problem of the opposing views may only be demonstrated by extreme and well-known examples. Is a constitutive majority allowed to adopt constitutional rules based on which everybody would have to brush their teeth three times a day and the elections would only be held every fifty years? The argumentation of the other camp is frequently faced with the problem of what conclusion may be drawn when a fundamental legal provision reflecting raw will of power does not violate any international agreements whatsoever if interpreted literally. What international norm is infringed when the remuneration of the President who was forced to resign is provided for by an amendment of the Fundamental Law?

To demonstrate how the two differences of opinion are reflected in the argument of a constitutional lawyer, it is sufficient to take a few examples from the Venice Commission's opinion relating to the Fourth Amendment to the Fundamental Law. In the Commission's argument, alongside the expressions reading "the Commission strongly criticised" the use of the adverb "usually" emerges which, based on the global conception of the constitution or the characteristics of foreign codified constitutions, intends to highlight the weak points of the Fundamental Law:

47. Finally, as concerns the level of regulation, Article IX.3 of the Fundamental Law is one of the provisions introduced by the Fourth Amendment containing rather detailed rules which might require amending from time to time and are therefore usually regulated by ordinary laws. 
Raising such provisions to the level of the Constitution withdraws them from constitutional review. (...)

57. Financial regulations for universities are an issue usually regulated by ordinary law. Raising this provision to the constitutional level has the effect of preventing review by the Constitutional Court. (...)

65. From the point of view of the Venice Commission in the framework of this Opinion, important issues are the vagueness of the criteria as well as the level of regulation. Article XXII.3 of the Fundamental Law is one of the provisions of the Fourth Amendment that contains detailed rules which are usually regulated by law and should not be part of a Constitution. Raising such provisions to the level of the Constitution has the effect of preventing review by the Constitutional Court. ${ }^{17}$

Although in each case the Commission argues that with this method of regulation the constitutional process deprives certain legislative areas of the possibility of constitutional review, the legislature and the supportive professional system of arguments may retaliate with an almost straightforward response. "Is it not usual? So what? Does this solution violate any international agreements?"

Based on this conception, the usage of the adverb "usually" could be interchangeable with the terms "ought not to" or "inelegant" which have as much normative force as the idea of how certain constitutions regulate certain areas in international practice.

In the situation where, in light of the above, professional assessment of a legislative product is made impossible $a$ priori by its own nature and by the political environment that defines and subsequently qualifies the "product" as an addition, the question is justified in asking what means of comparativism may be utilised to allow the Hungarian Fundamental Law to be "ranked" among international codified constitutions. In doing so, the methods of empirically inspired comparative law studies which for example "measured" the former Hungarian Constitution on a libertarian and state-centred scale ${ }^{18}$ should be avoided. How the circumstances of the adoption of the Hungarian Fundamental Law as well as the fundamental rules laid down therein comply with the minimum criteria of codified constitutions embodying the rule of law should be examined. Naturally, determining the minimum criteria may be carried out with some degree of arbitrariness since no matter how many international agreements set out the universal legal standards that pertain to the foundations of state structures under the rule of law; these standards continue to leave room for interpretation for constitutional lawyers. The definitions laid down in international agreements, for example, relating to the essence of judicial independence and, in a sense, following the interpretation of international judicial fora, provide ample room

17 Opinion on the Fourth Amendment to the Fundamental Law of Hungary adopted by the Venice Commission at its 95th Plenary Session, pp. 14, 16, 18. Venice, 14-15 June 2013.

18 See Law, Versteeg supra note 10 at pp. 1228-1229. 
for nation-states to comply with expectations with ease and dodge the legislative intention including the definition.

However, it is obvious that higher expectations may be perceived against codified constitutions by constitutional lawyers who regard the Fundamental Law as acceptable in general than may be literally deduced from international conventions. As cited, in his book on the Hungarian Fundamental Law, Trócsányi goes beyond the limitations deducible from the literal interpretation of international conventions when he refers to common European values. ${ }^{19}$ Not to mention László Sólyom who would consider the Fundamental Law acceptable with all its problems if it did not limit constitutional review in certain areas.

In vain may global constitutionality and convergence be discussed since due to the differences of the vague notions set out in international agreements and the above-mentioned conceptions of democracy, the debate over the Fundamental Law only leads to mutual cuts and thrusts if the minimum criterion that may be simultaneously compatible with the above-mentioned approaches remains unestablished.

It is seemingly strange that an author representing exclusive positivism, a pronounced movement of legal theory, has been selected as a basis for offering an acceptable standard for apparently irreconcilable constitutional perceptions. Raz's criteria, if separated from context and a life work of legal theory, are considered acceptable as a starting point because the seven criteria that he defined with pragmatic objectives and in order for the topic to be discussed may mean a type of intersection of the above-mentioned perceptions of democracy and constitution. On the one hand, these criteria go beyond the literal interpretation of what is laid down in international conventions. On the other hand, they set out much lower expectations than are reflected in either the opinions of the Venice Commission or the opinions fundamentally rejecting the Hungarian Fundamental Law. They may appear as criteria that are capable of serving as a starting point of European legislation relating to national constitutions.

Here, attention is primarily drawn to the problems which may separate the Hungarian Fundamental Law from the minimum criteria of codified constitutions.

\section{The Hungarian Fundamental Law and Joseph Raz's criteria relating to codified constitution}

As it was formerly noted, what Joseph Raz understood as the stricter sense of the "constitution" is the document or source of law which contains the functions and powers of a country's public bodies. ${ }^{20}$

19 See Trócsányi supra note 16 at p. 19.

20 See Raz supra note 15 at p. 324. 
1. The first element of these is marked by Raz with the expression "constitutive", which reveals a close connection in its content with the broad interpretation of the "constitution" as it refers to the fact that the Constitution is to define the basic powers of the main organs of the different branches of government. Raz formulated this as follows:

First, incorporating the thin sense, the constitution defines the constitution and powers of the main organs of the different branches of government. (This feature identifies the constitution as constitutive of the legal and political structure which is that legal system. $)^{21}$

The Hungarian Fundamental Law seems to comply with this expectation. Part 4 entitled "The State" of the Fundamental Law following the parts entitled "National Avowal", "Foundation" and "Freedom and Responsibility" enumerates the major state bodies and their basic scope of activities, the modes of their establishment and dissolution and, where appropriate, their responsibilities. However, the Fundamental Law offers little on the functions of these state bodies and, what is more, elaborating on the details in many cases - altogether in 27 areas - is entrusted to be regulated in Cardinal Acts. Although the Fundamental Law shall be adopted by a two-third majority vote of all Members of the Parliament, while Cardinal Acts shall be adopted by a two-third majority vote of the Members present, that is, with significant support, ${ }^{22}$ these two types of legislation may ensure a stable framework for defining state structures.

Two remarks, however, have to be made in this respect. On the one hand, even the two-third support minimum of Cardinal Acts does not mean that the Fundamental Law should not be expected to incorporate the details of the functioning of state structures. This is mostly the result of the fundamental feature of the Fundamental Law. In the absence of any provisions of merit beyond formal requirements, however, the Fundamental Law appears "empty" in a number of cases. Thus, for example, Article 6 on the Legislature sets out provisions on the proposal, the adoption and the promulgation of acts and constitutional scrutiny in merely nine subsections.

On the other hand, "practice" proved that adopting the Fundamental Law by a two-third majority vote does not guarantee that the content of the law will be consequential or perhaps constitutional in its entirety. An excellent example is the constitutional debate relating to the 2013 enactment of the Fourth Amendment to the Fundamental Law following a period of only two years. According to the motion submitted to the Constitutional Court by the Fundamental Rights Commissioner, internal contradictions appeared by way of the amendment, which lead to unconstitutionality in form as well. Adjudicating the motion, however, the Constitutional Court, applying a restrictive interpretation in its Ruling

21 Id. at p. 324.

22 Cf. Articles R.1 and S.4 of the Hungarian Fundamental Law. 
No. $12 / 2012$ (V. 24.) concluded that "the motion is in fact aimed at the fact that the Constitutional Court should compare in content the amendments to other provisions of the Fundamental Law and arguments and requirements developed in former rulings. The Constitutional Court believes that its authority does not extend this far since it would result in a content-related examination". ${ }^{23}$ If, however, the internal unity of the Fundamental Law may be subjected to debate, bringing Cardinal Acts to the front will carry in itself the fragility of the regulation of state structures as a time bomb. ${ }^{24}$

2. Raz's second requirement is that a codified constitution be created with the objective of being effective indefinitely and providing a framework for a country's legal system:

Second, it is, and is meant to be, of long duration: It is meant to serve as a stable framework for the political and legal institutions of the country, to be adjusted and amended from time to time, but basically to preserve stability and continuity in the legal and political structure, and the basic principles that guide its institutions. (The constitution is stable, at least in aspiration. $)^{25}$

In practice, this requirement means that the constitution, at least in principle, should ensure the unity and stability of the legal system even in the midst of changing social relations. Amendments and adjustments are allowed from time to time; however, the stability of the fundamentals is a requirement.

Regardless of some special circumstances, constitutions are adopted with this aim in mind and there is no doubt that the Hungarian Fundamental Law is not out of line here either. In addition, Raz supplements this requirement by noting that it is sufficient that this requirement is at least equal to constitutive aspirations.

To contest these aspirations would be impossible even after the Hungarian Fundamental Law was amended on various occasions in a surprisingly short time after its entry into force. Only constitutional books of etiquette may forbid the fact that the power vested with the necessary authority to the constitutional process could find a "solution" to a current situation through amending the constitution. However, such an Act does not refute the fact that the Fundamental Law framework was designed for long duration.

23 See Vincze, Attila. Az Alkotmánybíróság határozata az Alaptörvény negyedik módosításáról - Az alkotmánymódosítás alkotmánybírósági kontrollja. Jogesetek Magyarázata, Vol. 4., 2013, p. 6.

24 For the most thorough analysis concerning Cardinal Acts see Jakab, András, Szilágyi, Emese. Sarkalatos törvények a magyar jogrendben, MTA Law Working Papers, No. 2015/32, 2015.

25 See Raz supra note 15 at p. 324. 
It is an entirely different question how durable the Hungarian Fundamental Law will really be given that it was created without any political consensus. Although in the present situation, even with the amended electoral rules further strengthening the victor, it is difficult to imagine a two-third victory of a political force that represents a radically different ideology, failure to hold referenda or the lack of any party political agreements raises serious doubt as to the long-term stability of the Fundamental Law.

3. Ranking third on the Raz list is the requirement of "canonical formulation", that is, the constitution of a country should be contained in one or a small number of written documents. As Raz stressed:

Third, it has a canonical formulation. That usually means that it is enshrined in one or a small number of written documents. It (they) is (are) commonly referred to as the constitution. (The constitution-we say when referring to this feature-is written. $^{26}$

Unlike countries such as the United States, the constitutional system of Hungary has never been formulated by one legal act. Until 1949, Hungary had possessed a historical constitution. Following the regime change in 1989 "twothirds" Acts appeared and the Fundamental Law now effective is supplemented by a number of Cardinal Acts. What is more, for the purposes of interpreting the Fundamental Law, Article R.3 allows reliance upon the achievements of the historical constitution as well. ${ }^{27}$

The Fundamental Law does not define Cardinal Acts. Instead, it provides that "Cardinal Acts shall be Acts, for the adoption or amendment of which the votes of two-thirds of the Members of the National Assembly present shall be required". ${ }^{28}$ This "definition framework" is filled with content by actual authorisations, 50 of which in total may be found throughout the Fundamental Law providing, in other words, in which areas a Cardinal Act shall be adopted. This solution may lead to insecurity in the sense that, ultimately, any act may be declared as a Cardinal Act by amendment of the Fundamental Law. This elastic solution may broaden the limits of the constitution seen in a wider scope mentioned by Raz and all this to the liking of the current legislator.

However, it may not be stated that the Hungarian basic law would not satisfy this requirement. The framework laying down the foundations of the functioning of state structures and fundamental rights was set out in one written document.

26 Id.

27 "The provisions of the Fundamental Law shall be interpreted in accordance with their purposes, the National Avowal contained therein and the achievements of our historical constitution."

28 Article T.4 of the Fundamental Law. 
4. The fourth criterion of the constitution is that the basic law be the "superior law", that is, acts and other legislation that are contrary to it are invalid or inapplicable:

Fourth, it constitutes a superior law. This means that ordinary law which conflicts with the constitution is invalid or inapplicable. (The constitution is superior law. $)^{29}$

That the Hungarian Fundamental Law is undoubtedly the supreme law of the land, at least, in a formal sense, is also indicated by its adoption in 2011 by the National Assembly without any numbering, by "merely" naming it. This solution symbolically placed the Fundamental Law on a higher level than any other legislation. In a similar way, the fact that for the adoption of a new Fundamental Law or the amendment thereof, the votes of two-thirds of the Members of the National Assembly shall be required ${ }^{30}$ ensures formal "superiority" to the Fundamental Law, which requirement is not prescribed by the Fundamental Law in the case of other legislation. It is also worth mentioning Article T.3 providing that "no legal regulation shall conflict with the Fundamental Law". In light of the above, it is clear that the National Assembly unambiguously ensured the "superior" aspect of the Fundamental Law in a symbolic manner.

The superior character, however, is an important expectation from a contentspecific aspect as well. In this respect, it is also worth paying attention to the fact that, despite formal inferiority, certain Cardinal Acts are, in practice, raised to the level of the Fundamental Law by setting out some "outsourced" single parts. Article 24(4) of the Fundamental Law justifies this excellently in that it only allows conditional scrutiny of Cardinal Acts contrary to the Fundamental Law that are defined within basic regulations relating to the powers of the Constitutional Court (violation of certain human rights and perhaps in case of infringing the procedural rules of the legislative process). ${ }^{31}$

5. The "superior" aspect of the Fundamental Law prevails in merit only if the procedures and institutions - in accordance with the fifth expectation defined by Raz - are suitable for ensuring the "superior" aspect function in a country. As Raz noted:

29 See Raz supra note 15 at p. 324.

30 Article S.2 of the Fundamental Law.

31 "The Constitutional Court may, within its powers set out in Article 24(2)b) to e), review the Acts on the central budget, the implementation of the central budget, central taxes, duties and contributions, customs duties and the central conditions for local taxes for conformity with the Fundamental Law exclusively in connection with the rights to life and human dignity, to the protection of personal data, to freedom of thought, conscience and religion, or the rights related to Hungarian citizenship, and it may annul these Acts only for the violation of these rights. The Constitutional Court shall have the unrestricted right to annul also Acts having the above subject matter, if the procedural requirements laid down in the Fundamental Law for the making and promulgation of those Acts have not been met." 
Fifth, there are judicial procedures to implement the superiority of the constitution, that is judicial processes by which the compatibility of rules of law and of other legal acts with the constitution can be tested, and incompatible rules or legal acts can be declared inapplicable or invalid. (The constitution is justiciable.) ${ }^{32}$

For the purpose of the internal unity of the legal system, there must be a procedure named judicial procedure indicated by Raz, which is capable of ensuring the harmony of the codified constitution and every other act or legal instrument. Legislation or legal instruments that are incompatible with the constitution may be declared invalid under this procedure.

This is where the Hungarian Fundamental Law collides with one of Raz's criteria since, with the limitation of the Hungarian Constitutional Court's powers; the harmony of lower level legislation with the basic law cannot be assessed in certain cases. The limitation of the power of review took place already in 2010 with the amendment of the former Constitution, which was included in the Fundamental Law as well. ${ }^{33}$ According to this, while state debt exceeds half of the entire domestic product, the Constitutional Court, under subsequent scrutiny and constitutional complaint, may only examine the constitutionality of acts on public finance in case of certain fundamental rights having been violated. ${ }^{34}$

The limitation of the scope of the Constitutional Court, the elimination of the actio popularis in light of the division of powers, other amendments of rules establishing powers, changes in the election method of Constitutional Court Justices and the Chief Justice of the Constitutional Court, which was regarded as a sore point by those rejecting the changes resulting from the creation of the Fundamental Law in respect of the Constitutional Court, ${ }^{35}$ do not in the least violate Raz's criterion. By contrast, the fact that certain sets of legislation might be exempted from judicial review is contrary to this requirement.

At this point, an interpretation problem may be mentioned of course, which demonstrates the volatility of the entire problematic and, for example, even in the case of an international treaty relating to national constitutions what difficulties may be faced.

If the content of Raz's definition is only approached through grammatical interpretation, it may be further stated that the Hungarian Fundamental Law takes a stand in this respect as well. There is no expressis verbis mention in the definition reading "with regard to all legislation or legal acts". Thus, the legislator

32 See Raz supra note 15 at pp. 324-325.

33 Article 37(4) and 37(5) of the Fundamental Law.

34 Such examples are the right to life and human dignity, to the protection of personal data, to freedom of thought, conscience and religion, or the rights related to Hungarian citizenship.

35 See for example: Chronowski, Nóra. Az alkotmánybíráskodás sarkalatos átalakítása. MTA Law Working Papers, No. 2014/8, 2014. 
might argue as follows: there is a judicial procedure in Hungary that is intended to review the constitutionality of legislation and nothing more is demanded by Raz either. On the other hand, one might argue that no allowance whatsoever is to be found in the criterion that would permit to establish exceptions.

6. As for Raz's sixth condition, an amendment to the Constitution shall be more difficult to secure than ordinary legislation:

Sixth, while there usually are legal procedures for constitutional amendment, constitutional amendments are legally more difficult to secure than ordinary legislation. (The constitution is entrenched.) ${ }^{36}$

Whether it is about the framework of the Fundamental Law or the abovedescribed Cardinal Acts, the Hungarian Fundamental Law satisfies Raz's condition in both respects. It is relatively without difficulty based on processing the comparative constitutional literature that one is given an idea of how a codified constitution may be rendered more difficult to be changed with the use of technical legal instruments. The majority of these methods seeking to bind the hands of the subsequent legislative power is aimed at fixing the rules of a codified constitution so that they may not be altered with a generally sufficient political support to government. In other words, a fundamental law being the crowning jewel of the legal system accepted by wider political support may only be amended on conditions that are more difficult to meet compared to other legislation. ${ }^{37}$

In this regard, the Hungarian Fundamental Law imposes the weakest conditions on subsequent constitutive bodies since the adoption, modification or amendment of the Fundamental Law is contingent upon a qualified majority vote of the Parliament. However problematic one may regard this solution, it nevertheless satisfies Raz's requirement. On the other hand, that does not mean that such weak conditions facilitating the constitutional process should not have any side effects which may result in the failure of the Hungarian Fundamental Law to comply with the basic criterion in other aspects.

7. According to Raz's seventh and last condition, a codified constitution should reflect principles that are generally accepted:

Seventh, its provisions include principles of government (democracy, federalism, basic civil and political rights, etc) that are generally held to express the common beliefs of the population about the way their society should be governed. It serves, you may say, not only as a lawyers' law, but as the people's law. Its main provisions are generally known, command general consent, and are held to be the (or part of

36 See Raz supra note 15 at p. 325.

37 Kilényi, Géza. Az alaptörvény stabilitását szolgáló garanciák a külföldi alkotmányokban és nálunk. Jogtudományi Közlöny, 1996, Vol. 51., p. 110-124. 
the) common ideology that governs public life in that country. (The constitution expresses a common ideology. $)^{38}$

The extent to which the Hungarian Fundamental Law expresses common values accepted by the majority of the society is difficult to detect due to the very method of its adoption. The problems related to preferences are dealt with by a variety of Hungarian and foreign studies. ${ }^{39}$ A referendum to test this with an approximate accuracy would be suitable only if the constitution were presented to the population point by point (and even giving rise to the possibility of different interpretations of certain passages). Due to party political commitment, the opinions declared during the referendum distort preferences at least as much as elections in representative democracies usually distort the presentation of the opinion of the society in legislature. (The latter distortion prevails exponentially in disproportionate electoral law systems.) Yet, the referendum is capable of adequately channelling social preferences.

It could be clarified that the "opinion poll" called National Consultation ${ }^{40}$ that prepared the adoption of the Fundamental Law is not appropriate to reach this objective. Although such a procedure may serve election campaign goals quite well, it is unsuitable to assess social preferences for methodological reasons.

38 See Raz supra note 15 at p. 325.

39 Fleck, Zoltán, Gadó, Gábor, Halmai, Gábor, Hegyi, Szabolcs, Juhász, Gábor, Kis, János, Körtvélyesi, Zsolt, Majtényi, Balázs, Tóth, Gábor Attila. Vélemény Magyarország Alaptörvényéröl. Fundamentum, 2011, Vol. 15., pp. 61-77.; Küpper, Herbert. Zwischen Staatspaternalismus, Kollektivismus und liberalem Individualismus: Normative Grundlagen des Menschenbilds im neuen ungarischen Grundgesetz. In Csehi, Zoltán, Schanda, Balázs, Sonnevend, Pál (ed). Viva vox iuris - Tanulmányok Sólyom László tiszteletére 70. születésnapja alkalmából. Budapest: Dialóg Campus. 2012, pp. 215-239.; Pap, András László. Ki és mi magyar? Az Alaptörvény preferenciái kritikai perspektívából. In Gárdos-Orosz, Fruzsina, Szente, Zoltán (ed). Alkotmányozás és alkotmányjogi változások Európában és Magyarországon. Budapest: Nemzeti Közszolgálati Egyetem. 2014, pp. 245-263.; Majtényi, Balázs. Alaptörvény a nemzet akaratából. Állam - és Jogtudomány, 2014, Vol. 55., pp. 77-96.; Scheppele, Kim Lane. Hungary's Attacks on the Rule of Law and Why They Matter for Business. Financial Times, February 5, 2014. Available at <http:// blogs.ft.com/beyond-brics/2014/02/05/guest-post-hungarys-attacks-on-the-rule-of-lawand-why-they-matter-for-business> Accessed 31.03.2016.; Az Alaptörvény nem fejez ki közakaratot - interjú Sólyom Lászlóval. [online]. Available at <http://www.ugyvedvilag. $\mathrm{hu} /$ rovatok/napirend/az-alaptorveny-nem-fejez-ki-kozakaratot-interju-solyom-laszloval> Accessed 31.03.2016.

40 In Hungary, "National Consultation" was introduced by the Orbán Government following the government change in 2010 so that "we, Hungarians (...) may discuss every important issue" subject to the signature of the Prime Minister on the questionnaires sent to the citizens. According to the Opposition, the Consultation is aimed at gathering information on citizens' commitment that serves party political objectives, while the Government states that it intends to know social preferences in this way to aid legislation (or even the constitutional process). 
Naturally, science could provide methods of how to measure social preferences. The latest summary of these methods is found in the work of Murphy and Ackermann ${ }^{41}$ in which an almost entire arsenal of methodological tools are in array to aid in how one might be given a credible picture of individual preferences which, in their entirety, may lead one to social preferences and, ultimately, the reflection of a "common ideology" in the constitution.

Far be it for the authors to encourage legislators to use a preference list compiled by the application of these methods in a constitutional process. It may well be that such a vision would be contrary to the elementary necessities of the efficient functioning of modern and pluralistic societies. It is not only because one should rewrite the entire criminal code based on the measured preferences, but because, based on the above, the set of rules leading to the impairment of the functioning of the market economy could be integrated into the constitution. It would equally be without support if the value system of the constitution were suggested by an "elite" group of limited members analogous to the philosophers of Plato's Republic. Methods deemed more conservative but well established in Europe are preferred more because they may ensure a realistic channelling of social preferences in addition to requiring a qualified majority in the constitutional process. Without these methods (among which the referendum is the best-known one hampering the constitutional process), including in the constitution the common values and ideology worded by Raz beside the electoral law system excessively awarding the winner is a mere illusion.

Since the Hungarian Fundamental Law has not undergone a serious preference test assessing social preferences in a way that at least approximates acceptance based on the above-mentioned methodology, it is an intuition that the Hungarian Fundamental Law or some of its parts believably would not satisfy Raz's condition.

\section{Conclusion}

The paper aimed to sress tha the Fundamental Law of Hungary as well as the "two-third majority statutes" led to an international scandal. Studies have suggested that the method of acceptance of the new Fundamental Law and its content are unique in several aspects. The reviews of the Fundamental Law by scholars and international organizations showed contradictory opinions. The present paper argued, however, that such opposition is mainly due to differing conceptions of the ideal democratic society. We think that proponents of the Fundamental Law asserting national sovereignty and the supremacy of legislation accept any constitutional regulation that is backed by the necessary amount of votes. On the other hand, the opponents have disliked everything that has happened in Hungarian constitutional law since 2010 on the premises

41 Murphy, Ryan O., Ackermann, Kurt A. Theoretical and Measurement Issues in the Study of Social Preferences. Personality and Social Psychology Review, 2014, Vol. 18., pp. 13-41. 
of global constitutional values, the lack of consensus, self-restraint or elegance. We evaluated the Fundamental Law of Hungary through the lenses of Joseph Raz's seven constitutional criteria and we have come to the conclusion that the new constitutional regime meets all except one criterion described by Raz. We argued that the Fundamental Law is "constitutive", it looks "stable" enough, it is formulated "canonically", it functions as a "superior law", and it is "justiciable" as well as "entrenched". We found, however, that it was accepted rapidly, without any endorsement by the opposing parties or any referendum. Consequently, it cannot be demonstrated that it mediates general values ("common ideology") accepted by the whole society.

\section{References (alphabetical order)}

Annus, Taavi. Comparative Constitutional Reasoning: the Law and Strategy of Selecting the Right Arguments. Duke Journal of Comparative and International Law, 2004, Vol. 14, pp. 301-349.

Az Alaptörvény nem fejez ki közakaratot - interjú Sólyom Lászlóval. [online]. Available at $<$ http://www.ugyvedvilag.hu/rovatok/napirend/az-alaptorveny-nem-fejez-ki-kozakaratot-interju-solyom-laszloval> Accessed 31.03.2016.

Bóka, János. Az összehasonlító módszer alkalmazása az Alkotmánybíróság gyakorlatában. In Ambrus, István, Köblös, Adél, Strihó, Krisztina, Sulyok, Márton, Szalai, Anikó, Trócsányi, László (ed). Dikaiosz logosz - Tanulmányok Kovács István emlékére. Szeged: Pólay Elemér Alapítvány, 2012, pp. 17-26.

Choudhry, Sujit. Globalization in Search of Justification: Toward a Theory of Comparative Constitutional Interpretation. Indiana Law Journal, 1999, vol. 74, p. 819-892.

Christiansen, Thomas, Reh, Christine. Constitutionalizing the European Union. China: Palgrave Macmillan, 2009, p. 42.

Chronowski, Nóra. Az alkotmánybíráskodás sarkalatos átalakítása. MTA Law Working Papers, No. 2014/8, 2014.

Chronowsky, Nóra. Az alkotmányozás a globális alkotmányozás kontextusában. Jura, 2012, Vol. 18, pp. 251-259.

Fleck, Zoltán, Gadó, Gábor, Halmai, Gábor, Hegyi, Szabolcs, Juhász, Gábor, Kis, János, Körtvélyesi, Zsolt, Majtényi, Balázs, Tóth, Gábor Attila. Vélemény Magyarország Alaptörvényéröl. Fundamentum, 2011, Vol. 15., pp. 61-77.

Jakab, András, Szilágyi, Emese. Sarkalatos törvények a magyar jogrendben, MTA Law Working Papers, No. 2015/32, 2015.

Kilényi, Géza. Az alaptörvény stabilitását szolgáló garanciák a külföldi alkotmányokban és nálunk. Jogtudományi Közlöny, 1996, Vol. 51., p. 110-124.

Küpper, Herbert. Zwischen Staatspaternalismus, Kollektivismus und liberalem Individualismus: Normative Grundlagen des Menschenbilds im neuen ungarischen Grundgesetz. In Csehi, Zoltán, Schanda, Balázs, Sonnevend, Pál (ed). Viva vox iuris - Tanulmányok Sólyom László tiszteletére 70. születésnapja alkalmából. Budapest: Dialóg Campus. 2012, pp. 215-239.

Landau, David. Abusive Constitutionalism. UC Davis Law Review, 2013, Vol. 47, pp. 189-260.

Law, David S., Versteeg, Mila. The Evolution and Ideology of Global Constitutionalism. California Law Review, 2011, Vol. 99. pp. 1163-1257. 
Majtényi, Balázs. Alaptörvény a nemzet akaratából. Állam - és Jogtudomány, 2014, Vol. 55., pp. 77-96.

Murphy, Ryan O., Ackermann, Kurt A. Theoretical and Measurement Issues in the Study of Social Preferences. Personality and Social Psychology Review, 2014, Vol. 18., pp. $13-41$.

Opinion on the Fourth Amendment to the Fundamental Law of Hungary adopted by the Venice Commission at its 95th Plenary Session. Venice, 14-15 June 2013.

Pap, András László. Ki és mi magyar? Az Alaptörvény preferenciái kritikai perspektívából. In Gárdos-Orosz, Fruzsina, Szente, Zoltán (ed). Alkotmányozás és alkotmányjogi változások Európában és Magyarországon. Budapest: Nemzeti Közszolgálati Egyetem. 2014, pp. 245-263.

Scheppele, Kim Lane. Hungary's Attacks on the Rule of Law and Why They Matter for Business. Financial Times, February 5, 2014. Available at $<$ http://blogs.ft.com/ beyond-brics/2014/02/05/guest-post-hungarys-attacks-on-the-rule-of-law-andwhy-they-matter-for-business $>$ Accessed 31.03.2016.

Smits, Jan M. Comparative Law and its Influence on National Legal Systems. In Reimann, Mathias - Zimmermann, Reinhard (ed). The Oxford Handbook of Comparative Law. Oxford: Oxford University Press, 2006, pp. 477-512.

Raz, Joseph. Between Authority and Interpretation: On the Theory of Law and Practical Reason. Oxford: Oxford University Press, 2009.

Rehnquist, William H. Foreword. In Jackson, Vicki C., Tushnet, Mark (ed). Defining the Field of Comparative Constitutional Law. Westport-London: Praeger, 2002, pp. vii-ix.

Sulyok, Márton. Értelem és érzelem vagy büszkeség és balítélet? Alkotmánybíráskodás és alkotmányos identitás. Fontes Iuris, 2015, Vol. 1., pp. 27-39.

Trócsányi, László. Az alkotmányozás dilemmái. Budapest: HVG-Orac, 2014

Tushnet, Mark. The Inevitable Globalization of Constitutional Law. Virginia Journal of International Law, 2009, Vol. 56, pp. 985-1006.

Tushnet, Mark. The Possibilities of Comparative Constitutional Law. The Yale Law Journal, 1999, vol. 108, pp. 1225-1309.

Vincze, Attila. Az Alkotmánybíróság határozata az Alaptörvény negyedik módosításáról - Az alkotmánymódosítás alkotmánybírósági kontrollja. Jogesetek Magyarázata, Vol. 4., 2013, p. 6.

Weinrib, Lorraine E. Constitutional Conceptions and Constitutional Comparativism. In Jackson, Vicki C., Tushnet, Mark (ed). Defining the Field of Comparative Constitutional Law. Westport-London: Praeger, 2002, pp. 3-33. 